\title{
FSN-NU 0011
}

\section{THE COMPARATIVE EFFECT OF FISH AND BLOOD MEAL BASED DIETS ON THE GROWTH AND SURVIVAL OF JUVENILE TILAPIA (Oreochromis niloticus) IN CONCRETE TANK}

\author{
BEKIBELE, D.O., ANSA, E.J., AGOKEI, O.E., OPARA, J.Y., ALOZIE-CHIDI, V.C., ARANYO, A.A. \\ UZUKWU, P.U., GBULUBO, A.J., OKEREKE, A., AZUBUIKE,N. EZENWA,N., AND IBEMERE,I. \\ African Regional Aquaculture Centre Aluu, Port Harcourt
}

Copyright 2010, Fisheries Society of Nigeria.

This paper was prepared for presentation at the $25^{\text {th }}$ Annual International Conference and Exhibition in Administrative Staff College of Nigeria (ASCON), Topo-Badagry, Lagos, Nigeria, $25^{\text {th }}-29^{\text {th }}$ October, 2010.

This paper was selected for presentation by an FISON Program Committee following review of information contained in an abstract submitted by the author(s). Contents of the paper, as presented, have not been reviewed by the Fisheries Society of Nigeria and are subject to correction by the author(s). The material, as presented dos not necessarily reflect any position of the The material, as presented, does not necessanly reflect any position of the FISON mociety or Nigeria, its olficers, or members. Papers presented at ISON meetings are subject to publication review by Editoral Committees of Fis con of an part of consent of the Fisheries Society of Nigena is prohibited. Permission to reproduce in print is restricted to an abstract of not more than 300 words; illustrations may not be copied. The abstract must contain conspicuous acknowledgement of where and by whom the paper was presented. Write Librarian, Fisheries Society of Nigeria (FISON), P. O. Box 2607 Apapa, Lagos.

\section{ABSTRACT}

An experiment was carried out to find out the comparative effect of imported fish meal, blood meal and local fish waste based diets on the growth and survival of juvenile tilapia. (O. niloticus) in concrete tank. Four diets consisting of N.I.O.M.R. pelleted feed containing $40 \% \mathrm{CP}$, with imported fish meal, as the control and three others formulated with fresh, boiled cattle blood and local fish waste meal at $30 \%$ CP, were fed to juvenile tilapia with average initial weight of $55.24 \mathrm{~g}$ in four treatments and four replicates in a completely randomized design. Result indicated final body weights of 100.83, 96.54, 98.4 and 86.82 $\mathrm{g}$ and average body length of 18.47, 18.16, 18.4 and $18.14 \mathrm{~cm}$, for treatments 1 (control), 2 (fresh blood based diet), 3 (boiled blood based diet) and 4 (local fish waste meal based diet) respectively, with no significant difference between the treatments $(P>0.05)$. The same was also true for average daily weight gain of 0.41, 0.36, 0.31 and 0.28g. However, treatment 1 and 2 had better relative weight gain 93.69 and $80.21 \%$, than 3 and 4 at 62.37 and $64.85 \%$ respectively, $(P<0.05)$. The survival was $100 \%$ in all treatments. Treatment 2 was more cost effective at $\mathrm{A539.06/Kg}$ fish, followed by 1 with N667.52. Treatments 3 and 4 had the highest at N698.20 and N718.60 per $\mathrm{kg}$ fish. The trial showed that tilapia feed processed with fresh cattle blood performed as well as imported fish meal, boiled blood and local fish waste and in addition was more cost effective.

\section{INTRODUCTION}

Protein provides the major basis for growth, development and reproduction etc, in fish (Stiffens 1989, Kaushik 1995). The protein source is the major indicator of the quality of protein with fish meal excelling all other alternatives in fish feeding (Desilva, and Anderson, 1995). The nutritional practice is to combine animal and plant protein concentrates. The available nutrient in one complementing the deficient in the other (Jackson and Capper, 1982, Tacon and Jackson 1985). The availability of fish meal for large scale production of fish feed is highly suspect (Rosamond et al., 2000). It's use in Nigeria, is dependent on importation with resultant high cost and waste of foreign exchange. Cattle blood available in most abattoirs in Nigeria is currently not efficiently used. Harris (1980) asserted that the combined deficiency of cystine and methionine in blood meal could be remedied by fortifying with pure synthetic methionine which is available as a feed supplement. Ogunji and Wirth (2001) in their study on alternative protein sources as substitute for fish meal in the diet of young tilapia (O.niloticus) observed that a proper combination of Soya beans, blood meal (not more than 6\% level), groundnut cake and wheat bran could provide the $42-45 \%$ protein needed by the fish. Such 
combination could provide the low cost feed required for low cost of production (Webster et al, 1992, Tacon and Jackson, 1985) which is needed for tilapia production. This work was thus effected to find out the comparative effect of cattle blood made into feed in the fresh liquid state, boiled state, imported fish meal and local fish waste meal based diets on the growth and survival of tilapia and the resultant cost benefit effect on stagnant concrete tank, the system mostly used by farmers in Nigeria.

\section{MATERIALS AND METHODS}

Feed for the trial- Pelleted commercial feed (6 mm size) obtained from NIOMR Lagos, containing $40 \% \mathrm{cp}$ and made up of imported fish meal, defatted soya bean meal, and groundnut cake as crude protein sources and corn and wheat bran as carbohydrate sources, served as the control. Three other diets were formulated at $30 \% \mathrm{Cp}$ with $8.5 \% \mathrm{CP}$ contributed by fresh, boiled blood and local fish meal respectively as animal protein sources with soyabean cake as plant protein source and wheat bran and garri as carbohydrate sources. The formulae are as shown in Table 1. The materials were scaled out according to the formulae, ground, mixed and pelleted with a $6 \mathrm{~mm}$ die. The nutrient composition in all the diets were calculated as shown in Table 1.

Feeding Trial: The four diets were allotted to $1 \mathrm{~m}^{3}$ concrete tanks in the family testing unit at the African Regional Aquaculture Centre.

Table 1: Ingredient and calculated proximate composition of experimental diets

\begin{tabular}{lllll}
\hline Ingredients & $\begin{array}{l}\text { Diet 1 } \\
\text { (Control diet) }\end{array}$ & $\begin{array}{l}\text { Diet 2 } \\
\text { (Fresh blood) }\end{array}$ & $\begin{array}{l}\text { Diet 3 } \\
\text { (Boiled blood) }\end{array}$ & $\begin{array}{l}\text { Diet 4 } \\
\text { (Local fish meal) }\end{array}$ \\
\hline Wheat bran & 10.80 & 46.40 & 46.40 & 41.92 \\
Corn & 10.80 & - & - & - \\
Soya bean & 32.40 & 33.01 & 33.01 & 34.75 \\
Fish meal & 18.40 & - & - & 13.33 \\
Blood meal & - & 10.00 & 10.00 & - \\
Groundnut Cake & 34.60 & - & - & - \\
Garri & - & 5.00 & 5.00 & 5.00 \\
Vegetable oil & 0.70 & 5.00 & 5.00 & 5.00 \\
Vitamin/trace & 0.25 & 0.25 & 0.25 & 0.25 \\
mineral premix & & & & \\
Methionine & - & 0.35 & 0.35 & - \\
Vitamin C & 0.10 & 0.10 & 0.10 & 0.10 \\
\hline Total & $\mathbf{1 0 0 \%}$ & $\mathbf{1 0 0 \%}$ & $\mathbf{1 0 0 \%}$ & $\mathbf{1 0 0 \%}$ \\
\hline Proximate & & & & \\
composition: & & & & 30.50 \\
Crude protein & 44.38 & 30.44 & 30.44 & 8.60 \\
Ether extract & 5.23 & 8.14 & 8.14 & 5.25 \\
Crude fiber & 5.60 & 5.46 & 5.46 & 6.87 \\
Ash & 4.33 & 4.54 & 4.54 & 12.12 \\
Moisture & 11.60 & 12.54 & 11.54 & 36.16 \\
NFE & 28.86 & 38.88 & 39.88 &
\end{tabular}

(ARAC), Aluu, Port Harcourt, as four treatments each with 4 replicates in a completely randomized design. Eleven juvenile tilapia were stocked per tank at an average initial weight of 55.24g. Borehole water was supplied from a concrete reservoir. Water quality parameters such as $\mathrm{PH}$, temperature and DO were measured using the pencil type $\mathrm{PH}$ meter with temperature display and La Motte fresh water aquaculture test kit (Model AQ-2, code 3633-03) for DO every week.

At the beginning of the third month, electricity failure and damage to the borehole pump led to acute water shortage with resultant effect on water quality. Remediation measures included the agitation of the water in all the tanks to raise the DO level. 
Sampling was done every month and new weights and lengths determined. The new feeding rate was worked out based on the new biomass. At the end of the trial in 4 months, final weights and length were determined and the means of growth performance parameters were subjected to analysis of variance (ANOVA).

\section{RESULT AND DISCUSSION}

\section{Physico-Chemical parameters}

The result of water quality as shown on Table 2 indicated fair $\mathrm{pH}$ value of 7.07 for borehole water and $6.87,6.75,6.86$ and 6.87 for months $1,2,3$ and 4 averages for tank water, and temperature values of $28.9, \quad 28.1, \quad 30, \quad 28.4$ and $28.6^{\circ} \mathrm{C}$ respectively. Dissolved oxygen values were low at 2.35, 1.53 and $1.85 \mathrm{mg} / \mathrm{l}$. For borehole water and months 1 and 2 tank water, and depressingly low at $0.85 \mathrm{mg} / \mathrm{lit}$; in month 3 due to acute water shortage.
The values rose again to 2.89 following remediation action. All the diets had similar effect on the quality of tank water.

Growth performance: There was gradual increase in body weight within the first two months of the trial in all treatments (table 3), followed by a drop in the third month due to very low DO. This agrees with the finding of Okaeme (1990) that low DO retards the growth of juvenile fish. A rise occurred again with remediation action in the $4^{\text {th }}$ month. Condition factors (Table 4) improved in all the treatments for the first two months, dropping in the third till the end. Average final body weight of $100.83,96.4$ and $86.82 \mathrm{~g}$ and average body length of 18.47 , 18.16, 18.45 and $18.14 \mathrm{~cm}$ for treatments 1 (control), 2 (fresh blood), 3 (boiled blood) and 4 (local fish waste meal based diet) respectively.

Table 2: Physico-Chemical Parameters of borehole and tank water

\begin{tabular}{llllll}
\hline Parameters & Borehole & \multicolumn{2}{l}{ Experimental tank water } & & \\
& & Month 1 & Month 2 & Month 3 & Month 4 \\
\hline $\mathrm{PH}$ & 7.07 & 6.87 & 6.75 & 6.86 & 6.87 \\
$\mathrm{~T}^{\circ} \mathrm{C}$ & 28.90 & 28.10 & 30.00 & 28.40 & 28.60 \\
$\mathrm{DO}_{2} \mathrm{mg} /$ lit. & 2.35 & 1.53 & 1.85 & 0.85 & 2.89 \\
\hline
\end{tabular}

Table 3: Average monthly body weight of juvenile tilapia in grams

\begin{tabular}{llllll}
\hline Treatments & Initial & Month 1 & Month 2 & Month 3 & Mount 4 \\
\hline 1. & 52.50 & 81 & 110.83 & 91.98 & 100.83 \\
2. & 53.85 & 79.58 & 105.12 & 89.26 & 96.54 \\
3. & 61.45 & 83.46 & 103.19 & 92.61 & 98.4 \\
4. & 53.17 & 71.40 & 95.91 & 78.75 & 86.82 \\
\hline
\end{tabular}

Table 4: Average monthly condition factor

\begin{tabular}{llllll}
\hline Treatments & Initial & Month 1 & Month 2 & Month 3 & Mount 4 \\
\hline 1. & 1.36 & 1.99 & 2.28 & 1.68 & 1.60 \\
2. & 1.36 & 1.72 & 2.14 & 1.65 & 1.61 \\
3. & 1.51 & 1.73 & 2.04 & 1.60 & 1.57 \\
4. & 1.38 & 1.80 & 2.06 & 1.61 & 1.45 \\
\hline
\end{tabular}


Table 5: Growth performance, nutrient utilization and survival of juvenile tilapia fed the experimental diet.

\begin{tabular}{lllll}
\hline \multicolumn{1}{c}{$\begin{array}{c}\text { Parameters } \\
\text { Growth performance }\end{array}$} & Diet 1 (control) & Diet 2 (fresh blood) & Diet 3 (Boiled blood) & Diet 4 (Local fishmeal) \\
\hline Av. Initial body weight (g) & 52.50 & 53.85 & 61.45 & 53.17 \\
Av. Initial length (cm) & 15.67 & 15.82 & 15.98 & 15.66 \\
Av. Final body weight (g) & 100.83 & 96.54 & 98.40 & 86.82 \\
Av. Final length (cm) & 18.47 & 18.16 & 18.45 & 18.14 \\
Av. Weight gain (g) & 48.34 & 42.68 & 36.95 & 33.65 \\
Av. Daily weight gain (g) & 0.41 & 0.36 & 0.31 & 0.28 \\
Av. Relative weight gain \% & 93.69 & 80.21 & 62.37 & 64.85 \\
\hline
\end{tabular}

showed no significant difference (P> 0.05 ), Table 6. Average weight gain of $48.34,42.68, \quad 36.95$ and $33.65 \mathrm{~g}$ for treatments 1-4 respectively, also showed no significant difference $(\mathrm{P}>0.05)$. The same was true for average daily weight gain of $0.41,0.36,0.31$ and $0.28 \mathrm{~g}$. However relative weight gain was higher in treatments 1 and 2 at 93.69 and 80.21 than in treatments 3 and 4 at 62.37 and $64.85 \%$ respectively $(\mathrm{P}<0.05)$. This result contradicts the findings of Ogunji and Wirth (2001) who observed that blood meal inclusion rate not exceeding $6 \%$ may be recommended for O.niloticus and that beyond this level poor performance of fish was noticed and increased mortality. The level used was $10 \%$ and compared effectively with the fish meal based diet. The fresh blood type more so. The reason for this may not be unconnected with the fact that absorbing fresh blood in wheat bran and other materials and pelleting before sun drying ensures that nutrients which could be destroyed by heat in the conventional method of processing blood meal are saved as observed by Sonaiya (1988). The combination also improves the ratio of leucine: Isolencine and removes the antagonism between the two observed by Taylor et al (1977), and fortification with methionine takes care of the deficiency in blood meal and soyabean meal as stated by Haris (1980). The relatively poor growth rate in all the treatments was due to the low DO level particularly after the second month.

Survival: Survival was $100 \%$, showing that tilapia could survive even beyond $6 \%$ level of blood inclusion, contrary to the observation of Ogunji and Wirth (2001). Cost Effectiveness: Diet 2 (fresh blood diet) produced $1 \mathrm{~kg}$ of tilapia at the lowest cost of N539.06 (Table 7), followed by diet 1 (control) with N667.52. Diets 3 and 4 , the boiled blood and local fish meal based diets had the highest cost at $\mathrm{N} 698.20$ and $\mathrm{N718.06}$ respectively for every $1 \mathrm{~kg}$ of the fish produced. The high cost was due to the poor growth in all the treatments.

\section{CONCLUSION}

The study showed that blood meal compares favourably with fish meal particularly when used fresh in processing the feed for juvenile tilapia. It is also more cost effective. 
Table 6: Estimation of cost effectiveness.

\begin{tabular}{|c|c|c|c|c|c|c|c|c|c|}
\hline \multirow[b]{2}{*}{ Ingredients } & \multirow[b]{2}{*}{$\begin{array}{l}\text { Cost/kg } \\
\text { Ingred. } \\
\text { (N) }\end{array}$} & \multicolumn{2}{|c|}{ Diet 1} & \multicolumn{2}{|c|}{ Diet 2} & \multicolumn{2}{|c|}{ Diet 3} & \multicolumn{2}{|c|}{ Diet 4} \\
\hline & & $\begin{array}{l}\text { Kg ing. } \\
/ 100 \mathrm{~kg} \\
\text { diet }\end{array}$ & $\begin{array}{l}\text { Cost/ } \\
\text { 100kg } \\
\text { diet }(\mathrm{N})\end{array}$ & $\begin{array}{l}\text { Kg ing. } \\
\text { /100kg } \\
\text { Diet }\end{array}$ & $\begin{array}{l}\text { Cost/ } \\
\text { 100kg } \\
\operatorname{diet}(\mathrm{N})\end{array}$ & $\begin{array}{l}\text { Kg ing. } \\
/ 100 \mathrm{~kg} \\
\text { diet }\end{array}$ & $\begin{array}{l}\text { Cost/ } \\
100 \mathrm{~kg} \\
\operatorname{diet}(\mathrm{N})\end{array}$ & $\begin{array}{l}\text { Kg ing. } \\
/ 100 \mathrm{~kg} \\
\text { diet }\end{array}$ & $\begin{array}{l}\text { Cost/ } \\
100 \mathrm{~kg} \\
\operatorname{diet}(\mathrm{N})\end{array}$ \\
\hline Wheat bran & 36 & 10.80 & 388.80 & 46.40 & 1670.40 & 46.40 & 1670.40 & 41.92 & 1509.12 \\
\hline Corn & 60 & 10.80 & 648 & - & - & - & - & - & - \\
\hline Soya bean & 140 & 32.40 & 4536 & 33.01 & 4621.40 & 33.01 & 4621.40 & 34.75 & 4865 \\
\hline $\begin{array}{l}\text { Imported } \\
\text { fishmeal }\end{array}$ & 350 & 18.40 & 6449 & - & - & - & - & - & - \\
\hline Blood meal & 120 & - & - & 10 & 1200 & 10 & 1200 & - & - \\
\hline Garri & 145 & - & - & 5 & 725 & 5 & 725 & 5 & 725 \\
\hline Local fishmeal & 250 & - & - & - & - & - & - & 13.33 & 3332.5 \\
\hline Vegetable oil & 350 & 0.70 & 245 & 5 & 1750 & 5 & 1750 & 5 & 1750 \\
\hline Premix & 1000 & 0.25 & 250 & 0.25 & 250 & 0.25 & 250 & 0.25 & 250 \\
\hline Methionine & 1400 & - & & 0.35 & 490 & 0.35 & 490 & - & - \\
\hline Vitamin C & 5000 & 0.10 & 500 & 0.10 & 500 & 0.10 & 500 & 0.10 & 500 \\
\hline GNC & 110 & 34.60 & 3806 & - & - & - & - & - & - \\
\hline $\begin{array}{l}\text { Total } \\
\text { Cost } \\
\text { effectiveness: }\end{array}$ & & $100 \mathrm{~kg}$ & $16,813.8$ & $100 \mathrm{~kg}$ & $11,206.8$ & 100kg & $11,206.8$ & $100 \mathrm{~kg}$ & $12,937.62$ \\
\hline $\begin{array}{l}\text { 1. Cost } / \mathrm{kg} \text { diet } \\
\text { (A) }\end{array}$ & & & 168.14 & & 112.07 & & 112.07 & & 129.38 \\
\hline $\begin{array}{l}\text { 2. Amount of } \\
\text { feed required to } \\
\text { produce } 1 \mathrm{~kg} \\
\text { fish }(\mathrm{FCR})\end{array}$ & & 3.97 & & 4.81 & & 6.23 & & 5.55 & \\
\hline $\begin{array}{l}\text { 3. Cost } \\
\text { effectiveness } \\
\text { (1) } \mathrm{X}(2)\end{array}$ & & & 667.52 & & 539.06 & & 698.20 & & 718.06 \\
\hline
\end{tabular}

\section{REFERENCES}

Desilva, S.S. and T.A. Anderson, 1995. Fish Nutrition in Aquaculture. Chapman and Hall, London 319pp.

Harris, L.E. 1980. Feedstuff, fish feed technology-Lectures presented at the FAO/UNDP Training course in Fish Feed Technology held at the College of Fisheries, University of Washington, Seatle, Washington USA. $9^{\text {th }}$ October- $15^{\text {th }}$ December 1978. ADCP/REP/80/11. Pp.156157.

Jackson, A.J. and B.S. Capper 1982. Investigations into the requirement of the Tilapia. Sarotherodon mossambicus for dietary methionine, lysine and arginine in semi purified diets. Aquaculture, 29: 280-297.

Kaushik, S.J. 1995. Amino acid requirement, protein and energy utilization. In: From Feed to feed symp. Technological and Nutritional aspects of state feed production. Utrecht, Netherlands.

Ogunji, J.O. and Wirth, M., 2001. Alternative protein sources as substitutes for fish meal in the diet of young Tilapia Oreochromis niloticus (Linn). The Israeli Journal of Aquaculture-Bamidgeh 53 (1), 2001, 34-43.

Okaeme, A.N., 1990. Prospects and problems of fresh water fish ponds fertilizer using animal droppings in subsistence fish farming. The Nigerian Journal of agricultural extension. Vol. 5, Nos. 1 \& 2, Pages 58-64.

Rosamond, L. Naylor, Rebecca, J. Goldburg, Jurgen, H. Bimavera, Nils Kautsky, Malcom, C.M. Beveridge, Jason Clay, Carl Folke, Jane Lubchenco, Harold Mooney and Max Troel, 2000. Effect of 
Aquaculture on Word Fish supplies. Nature 405, 1017-1024. Doi:10.1038/350/6500.

Sonaiya, E.B., 1988. Animal by -products and their potential for commercial livestock feed production- A paper presented at the workshop on alterative formulation of livestock feeds in Nigeria, held at the Agricultural and Rural Management Training Institute (ARMTI) Ilorin, November 21-25 1988.

Tacon, A.G. and A.J. Jackson 1985. Utilization of Conventional and unconventional protein sources in practical fish feeds. Pp 119-145. In: C.B. Cowey, A.M. Mackie and J.C. Bell (eds). Nutrition and Feeding in Fish. Academic Press, London.

Stiffens, W., 1989. Principles of Fish Nutrition. Ellis Horwood, London. 384pp.

Taylor, S.J., J.A. Cole and D. Lewis, 1977. An interaction of Leucine, isoleucine and valine in the diet of the growing pig. Proc. Nutr. Soc., $36: 36^{\mathrm{A}}$. 